\title{
1 Nitrate pollution of groundwater; all right..., but nothing else?
}

2 Anna Menció ${ }^{1}$, Josep Mas-Pla ${ }^{1,2}$, Neus Otero ${ }^{3}$, Oriol Regàs ${ }^{1}$, Mercè Boy-Roura ${ }^{2}$, Roger Puig ${ }^{3}$, Joan

\author{
Bach $^{5}$, and Cristina Domenech ${ }^{3}$, Albert Folch ${ }^{5}$
}

$4{ }^{1}$ Grup de Geologia Aplicada i Ambiental (GAiA), Centre de Recerca en Geologia i Cartografia Ambiental (Geocamb), Dept.

5 de Ciències Ambientals, Universitat de Girona, Spain, e-mail: anna.mencio@udg.edu

$6 \quad 2$ Institut Català de Recerca de l'Aigua (ICRA), Spain, email: jmas@icra.cat.

$7 \quad{ }^{3}$ Grup de Mineralogia Aplicada i Geoquímica de Fluids, Dept. de Cristal-lografia, Mineralogia i Dipòsits Minerals, Facultat 8 de Geologia, Universitat de Barcelona, Spain, email: notero@ub.edu.

$9{ }^{4}$ Àrea de Geodinàmica Externa i Hidrogeologia, Dept. de Geologia, Universitat Autònoma de Barcelona, Bellaterra, Spain, 10 email: joan.bach@uab.cat.

$11{ }^{5}$ Grup d'Hidrologia Subterrània, Dept. D’Enginyeria del Terreny, Cartogràfica i Geofísica. Universitat Politècnica de 12 Catalunya-Barcelona Tech, Spain, email: folch.hydro@gmail.com.

14 Submited to: Science of the Total Environment

16 KEY WORDS: nitrate pollution, hydrochemistry, water-rock interaction, multivariate 17 analysis, groundwater

\section{ABSTRACT}

19 Contamination from agricultural sources and, in particular, nitrate pollution, is one of the main concerns in groundwater management. However, this type of pollution entails the

21 entrance of other substances into the aquifer, as well as it may promote other processes. In this study, we deal with hydrochemical and isotopic analysis of groundwater samples from

23 four distinct zones in Catalonia (NE Spain), which include different lithological units, to 24 investigate the influence of manure fertilization on the overall hydrochemical composition of groundwater. Results indicate that high nitrate concentrations, resulting from intense manure 
application, homogenize the contents of the major dissolved ions (i.e.; $\mathrm{Cl}^{-}, \mathrm{SO}_{4}{ }^{2-}, \mathrm{Ca}^{2+}, \mathrm{Na}^{+}$,

$27 \mathrm{~K}^{+}$, and $\mathrm{Mg}^{2+}$ ). Moreover, positive linear relationships between nitrate and some ions are

28 found indicating the magnitude of the fertilization impact on groundwater hydrochemistry.

29 Nevertheless, the increasing concentration of specific ions is not only attributed to the manure

30 input, but to the enhancing effect of manure and slurry upon the biogeochemical processes

31 that control water-rock interactions. Such results raise awareness that such processes should

32 be evaluated in advance in order to assess adequate groundwater resources assessment.

\section{Highlights}

34 - The effects of nitrate pollution have been evaluated in five different aquifer types

35 - Statistical and multivariate analyses are used to identify groundwater changes

36 - Agricultural pollution modifies groundwater conditions and geochemical processes

\section{INTRODUCTION}

Nitrate occurrence and transport in aquifers have been widely studied since it is one of the major threats in groundwater, and most aquifers in agricultural areas are affected by this contaminant (Spalding and Exner, 1993; EEA, 2012). Most of the papers that focused on nitrate pollution study, by means of hydrochemical and isotopic data, nitrate trends in groundwater at different scales to identify potential sources of pollution and build-up hydrogeochemical models to understand the behavior of nitrate polluted aquifers (for instance, Burg and Heaton,1998; Hudak, 2000; Katz et al., 2004; Masetti et al., 2008; Vitòria et al., 2008; Carbó et al., 2009; Kaown, et al., 2009; Menció et al., 2011; Boy-Roura et al., 2013). However, agricultural pollution due to a long and continued application of organic fertilizer (slurry and manure) may not only entail an increase on this ion in aquifers. On the one hand, other substances present in manure also enter into the groundwater system, such as 
50 ions, metals, emerging organic contaminants, or even microorganisms. On the other hand, 51 these substances interact with the subsurface environment, modifying groundwater conditions, enhancing geochemical processes and even modifying groundwater communities (Cho et al., 2000; Böhlke, 2002; Murray et al., 2010; Stein et al., 2010; Korbel and Hose, 54 2011; Lapworth et al., 2012; Korbel et al., 2013; Choi et al., 2013).

55 In this study, we look for the evidence of the changes that manure application exerts on the major components concentrations by conducting an analysis of a large hydrochemical database, including isotopic data, of nitrate polluted aquifers representative of several geological environments. Our aim is to analyze whether manure and slurry application lead to a loss of the hydrogeological fingerprint of the geological background, and whether the resulting groundwater composition is only caused by mixing with manure lixiviates or by changes in biogeochemical processes.

Manure applied as fertilizer has a complex chemical composition. For instance, Vitòria (2004) analyzed its composition from several farms in Osona (Catalonia, NE Spain) and reported that the concentration of some major inorganic components in pig manure, the most used organic fertilizer in the studied areas in Catalonia (NE Spain), is notably larger than their natural values in groundwater. This is the reason why its impact on groundwater hydrochemistry must be evaluated to avoid misinterpretation of supposedly hydrochemical natural data.

Samples for this study belong to four distinct regions in Catalonia, all of them classified as Nitrate Vulnerable Zones (NVZs) as a result of the transposition of the Nitrate Directive (ND) $91 / 676 /$ EC. In fact, NVZs in Catalonia cover up to $40 \%$ of the total area, and half of them show nitrate concentrations higher than $40 \mathrm{mg} / \mathrm{L}$, affecting 17 out of the 53 groundwater bodies which are at risk of not meeting the European Water Framework Directive goals (ACA, 2007; Boy-Roura, 2013). In this study, we analyze datasets from the 
following NVZs, according to published results in the Selva basin (Folch et al., 2011; Menció et al., 2012; Puig et al., 2013), Empordà basin (Puig, 2014), Osona region (Vitòria et al., 2008; Otero et al., 2009; Menció et al., 2011; Boy-Roura et al., 2013), and Garrotxa area (based on still unpublished data). According to their lithologies, five groups of aquifers are distinguished (Figure 1 and Figure 2):

- Group 1: Aquifers in igneous rocks, especially granite and granodiorite and, in a lesser degree, in metamorphic rocks such as shale, schist, marble, and gneiss. These aquifers are mainly located in the ranges surrounding the Selva and Empordà basins. Hydrochemically, they present $\mathrm{Ca}^{2+}-\mathrm{HCO}_{3}{ }^{-}$and $\mathrm{Ca}^{2+}-\mathrm{HCO}_{3}{ }^{-}-\mathrm{Cl}^{-}$facies, tending to evolve to $\mathrm{Na}^{+}-\mathrm{HCO}_{3}^{-}$

- Group 2: Aquifers in sedimentary rocks, mainly Paleogene sedimentary rocks, including detritic, organic and chemical sedimentary rocks, such as conglomerates, sandstones, siltstones, limestones, marls, and gypsum deposits. Although these aquifers are present in all the study areas, they are mainly exploited in Osona and Garrotxa, and with a minor extent in Empordà. Main hydrochemical facies are $\mathrm{Ca}^{2+}$ $\mathrm{HCO}_{3}{ }^{-}, \mathrm{Ca}^{2+}-\mathrm{Mg}^{2+}-\mathrm{HCO}_{3}{ }^{-}$or $\mathrm{Ca}^{2+}-\mathrm{SO}_{4}{ }^{2-}$.

- Group 3: Aquifers in sediments derived from igneous and metamorphic rocks. The arkosic sands, gravels and silt layers of the Neogene deposit that filled the Empordà and Selva areas, and the more recent Quaternary alluvial formations associated to the main rivers in these basins, are the weathering products of the main range areas, mainly located in the Pyrenees Montseny-Guilleries and Gavarres ranges. They show similar facies than Group 1.

- Group 4: Aquifers in sediments derived from sedimentary rocks. These aquifers are located in Osona and Garrotxa basins, and constitute the Quaternary alluvial aquifers and surface formations in these areas. Their facies are analogous to those of Group 2. 
- Group 5: Aquifers in volcanic materials. In this group of aquifers there is a broad variety of materials, from phreatomagmatic and pyroclastic deposits to basaltic lava flow locally interleaved by sedimentary (alluvial) levels, which may locally be the most productive units. These materials are mainly located in the Garrotxa area, but volcanic lithologies also constitute aquifers in some parts of the Selva basin. This group shows the lowest $\mathrm{EC}$ values with $\mathrm{Ca}^{2+}-\mathrm{HCO}_{3}{ }^{-}$or $\mathrm{Ca}^{2+}-\mathrm{Mg}^{2+}-\mathrm{HCO}_{3}{ }^{-}$facies.

\section{METHODOLOGY}

Field surveys, in the studied datasets (Folch et al., 2011; Menció et al., 2012; Puig et al., 2013; Puig, 2014; Otero et al., 2009; Menció et al., 2011; Boy-Roura et al., 2013), were conducted from 2006 to 2013. A total number of 204 groundwater sampling locations constitute the whole dataset - distributed as Selva basin: 37 samples; Empordà basin: 45; Osona region: 57; Garrotxa area: 65- and they are classified according to the five described lithological groups (Table 1).

Similar analytical procedures for hydrochemical and isotopic analysis were followed at each studied region. Specific details are described in each of the given references. Concentration units are reported in $\mathrm{mg} / \mathrm{L}$. Most of the samples had an ionic mass balance error between $\pm 5 \%$. Isotope $\delta$-notation for water isotopes is expressed in terms of the \%o deviation of the isotope ratio of the sample relative to that of the V-SMOW standard. Analytical errors are $\pm 0.06 \%$ for $\delta^{18} \mathrm{O}$ and $\pm 0.7 \%$ for $\delta \mathrm{D}$. Nitrate isotope notation is also expressed in terms of $\delta$ (\%) relative to that of the international standards AIR (atmospheric $\mathrm{N}_{2}$ ) for $\delta^{15} \mathrm{~N}$. Precision $(\equiv 1 \sigma)$ of the samples are $\pm 0.3 \%$ and $\pm 0.4 \%$, for $\delta^{15} \mathrm{~N}_{\mathrm{NO} 3}$ and $\delta^{18} \mathrm{O}_{\mathrm{NO} 3}$, respectively.

The SPSS program (version 19, 2010, SPSS Inc.) was used to conduct the different statistical analyses. Differences between aquifer hydrochemical parameters were analyzed considering the Kruskal-Wallis and Mann-Whitney U tests, for non-parametric data, since none of the 
parameters were normally distributed. In addition, a Principal Component Analysis (PCA)

was conducted in order to identify associations between variables and samples. The associations obtained through a PCA, based on similar magnitudes and variations in chemical, physical, and isotopic values in the groundwater samples composition, are adequate to indicate the influence of human factors, hydrochemical processes, or even, the origin of groundwater (for instance, Helena et al., 2000; Menció and Mas-Pla, 2008; Menció et al., 2013; Re et al., 2014).

\section{RESULTS AND DISCUSSION}

134 At a first glance, hydrochemical characteristics of groundwater samples with low $\mathrm{NO}_{3}{ }^{-}$ 135 content (below the health standard limit of $50 \mathrm{mg} \mathrm{NO}_{3}^{-} / \mathrm{L}$ ) reflect the dominant role of 136 lithology in the composition, as observed in Figure 2. Mean and standard deviation values 137 (Table 1) and boxplot shapes of selected parameters (EC, $\mathrm{Cl}^{-}, \mathrm{SO}_{4}{ }^{2-}, \mathrm{Na}^{+}, \mathrm{Ca}^{2+}$; Figure 2) for samples with low nitrate content, reflect the differences among aquifer types attributed to distinct lithology, showing the hydrochemical characteristics of groundwater samples under natural conditions. For instance, aquifers in groups 1 and 3, including igneous and metamorphic aquifers and sediments derived from these rocks, do not show significant differences between concentrations of the major hydrochemical components (with p-values between 0.089 and 0.881 ). These aquifers, for instance, present significant differences when compared with groups 2 and 4, representing aquifers in sedimentary rocks and in sediments derived from these rocks, for ions such as $\mathrm{Cl}^{-} \mathrm{Na}^{+}$, and $\mathrm{Ca}^{2+}$ (p-values ranging from values $<0.001$ to 0.038 ). Contrarily, hydrochemical characteristics of groundwater at high-nitrate concentrations ( $>50 \mathrm{mg} \mathrm{NO}_{3}^{-} / \mathrm{L}$; Figure 2 ) seem to homogenize their concentrations despite lithological differences, presenting wider ranges for major ions distribution and erasing the 
main differences in their hydrochemical composition of the distinct groups observed at low

$150 \mathrm{NO}_{3}{ }^{-}$samples.

151 In detail, when samples of low and high nitrate content for each lithological aquifer group are 152 compared, significant higher EC values are observed in the most polluted wells ( $p$-values ranging from 0.006 to values lower than 0.001 ). Higher EC values are related to significant higher concentrations of ions: $\mathrm{Cl}^{-}, \mathrm{SO}_{4}{ }^{2-}, \mathrm{Na}^{+}$and $\mathrm{Ca}^{2+}$ (Table 1). An exception are samples of group 1, which do not show significant differences in any of these parameters between low and high nitrate groups ( $\mathrm{p}$-values ranging from 0.123 for $\mathrm{Ca}^{2+}$ to 0.877 for $\mathrm{Cl}^{-}$), since some of these samples belong to thermal and/or $\mathrm{CO}_{2}$-rich systems. Geochemical evolution in such environments overlays the chemical contribution of manure inputs. In addition, it is worth mentioning that these $\mathrm{Cl}^{-}$and $\mathrm{Na}^{+}$higher concentrations are not detected in wells located in aquifer group 3 (in sediments derived from igneous and metamorphic rocks, and p-values of 0.684 and 0.844 , respectively), where natural processes can also favor high $\mathrm{Cl}^{-}$and $\mathrm{Na}^{+}$ concentrations.

It is also relevant that fewer hydrochemical differences are detected when high nitrate concentration sample populations for the different aquifers are compared (Figure 2 and Table 1). As expected due to lithological similarity, no significant differences are detected between groups 1 and 3 (p-values ranging from 0.087 for $\mathrm{SO}_{4}{ }^{2-}$ and 0.906 for $\mathrm{Cl}^{-}$), neither between groups 2 and 4 (p-values between 0.050 for $\mathrm{HCO}_{3}{ }^{-}$and 0.732 for $\mathrm{SO}_{4}{ }^{2-}$ ). Nevertheless, when samples with high nitrate concentrations of group 1 and 2 are compared, only significant differences in $\mathrm{SO}_{4}{ }^{2-}$ and $\mathrm{K}^{+}$are detected (p-values of 0.024 and 0.023 ), while other components show similar concentration ranges. Furthermore, differences among high nitrate concentrations samples of groups 1 and 4 are only evident for $\mathrm{Ca}^{2+}$ and $\mathrm{K}^{+}$(p-values of 0.018 and 0.011); comparing samples of groups 2 and 3, significant differences are reduced to $\mathrm{Mg}^{2+}$ and $\mathrm{K}^{+}$(with p-values $<0.001$ ); and, differences between samples of groups 1 and 5 with high 
nitrate concentrations are significant for $\mathrm{Na}^{+}$and $\mathrm{K}^{+}$(p-values of 0.014 in both cases). Indeed, this group 5 shows the largest differences with the rest of the aquifer groups for high $\mathrm{NO}_{3}{ }^{-}$ samples. In volcanic materials, nitrate pollution is clearly lower than in the rest of the studied aquifers, with an overall mean value of $30.90 \pm 3.81 \mathrm{mg} / \mathrm{L}$ (Table 1). In this case, high nitrate concentration samples presented differences with respect to nitrate for samples of groups 2, 3 and 4 (p-values of $0.026,0.027$ and 0.031 , respectively). Between group 5 and these other groups, significant differences were also observed in $\mathrm{EC}, \mathrm{Cl}^{-}, \mathrm{Ca}^{2+}$ and $\mathrm{SO}_{4}{ }^{2-}$ (p-values ranging from $<0.001$ to 0.044 ); besides, significant differences were detected between group 1825 and groups 2 and 3 for $\mathrm{Ca}^{2+}(\mathrm{p}$-values $<0.001)$; and, with group 3 for $\mathrm{K}^{+}$and $\mathrm{Mg}^{2+}(\mathrm{p}$-values 183 of 0.008 and 0.004 , respectively).

184 Complementarily, two Principal Component Analyses were conducted to determine the 185 different relationships among samples and variables. The first one considered all available 186 samples, a total number of 204; and considered eleven variables, including: $\mathrm{EC}$, pH, total 187 aqueous concentration of $\mathrm{HCO}_{3}{ }^{-}, \mathrm{Cl}^{-}, \mathrm{SO}_{4}{ }^{2-}, \mathrm{Ca}^{2+}, \mathrm{Mg}^{2+}, \mathrm{Na}^{+}$and $\mathrm{K}^{+}$, and $\delta^{18} \mathrm{O}$ and $\delta \mathrm{D}$. In the 188 second analysis, the dataset included only those samples that, in addition to the mentioned 189 variables, also included nitrate isotopic data $\left(\delta^{15} \mathrm{~N}_{\mathrm{NO} 3}\right)$. In this analysis the number of samples 190 was reduced to 158 , as in $32 \%$ of them (mainly from group 5) lacked the nitrate isotopic 191 information. By conducting both statistical analyses we seek illustrating whether 192 denitrification processes are relevant on the understanding of the hydrochemical changes in 193 groundwater related to nitrate pollution. This is the reason why both analyses are shown 194 herein, and compared.

195 In the first PCA, variables as $\mathrm{pH}, \mathrm{HCO}_{3}{ }^{-}, \mathrm{K}^{+}$and $\delta \mathrm{D}$ were ruled out of in order to obtain 196 better values of the goodness-of-fit statistics. Thus, a PCA conducted with the 7 remaining 197 variables had a Barlett chi-square statistic of 1241.6 (for 28 degrees of freedom and a 198 minimum significance level of $<0.001$ ), and a value of sampling adequacy (MSA) obtained 
by the Kaiser-Meyer-Olkin of 0.732 . In the second analysis, the final solution considered 8 variables, and had a better fit with a Barlett chi-square statistic of 1085.5 (for 36 degrees of freedom and a minimum significance lower than 0.001 ), and a MSA of 0.758 .

Four varifactors (VF) were obtained in both analyses, explaining $91.59 \%$ and $88.19 \%$ of the total variance, respectively. In each PCA, these varifactors explained the same processes and associations of variables; excepting natural attenuation, which was only considered in the second one as $\delta^{15} \mathrm{~N}_{\mathrm{NO} 3}$. For this reason, only the scores and samples distribution obtained in the second PCA are shown in Table 2 and Figure 3. Thus, after a Varimax rotation, the final VFs were interpreted as follows:

- VF1 includes $\mathrm{SO}_{4}{ }^{2-}, \mathrm{Mg}^{2+}, \mathrm{Ca}^{2+}$, and $\mathrm{EC}$, explaining a $32.53 \%$ of the total variance. This VF1 stands for water-rock interaction processes, specifically in sedimentary formations where gypsum dissolution occurs, since VF1 highest values are obtained in samples located in aquifers belonging to groups 2 and 4, where these processes have been described to govern groundwater hydrochemistry (Figure 3a; Menció et al., 2011; Soler et al., 2014).

- VF2 represents the $20.41 \%$ of variability of the data. It mainly includes $\mathrm{NO}_{3}{ }^{-}$, with a lower participation of $\mathrm{Ca}^{2+}$, EC and $\mathrm{Cl}^{-}$. VF2 has been interpreted as nitrate pollution, showing the direct relationship between $\mathrm{NO}_{3}{ }^{-}$and $\mathrm{EC}, \mathrm{Ca}^{2+}$ and $\mathrm{Cl}^{-}$variables.

- With a $20.23 \%$ of the total variance, VF3 is participated by $\delta^{18} \mathrm{O} \mathrm{Na}^{+}$and $\mathrm{Cl}^{-}$. This VF3 is linked to the recharge altitude of groundwater samples, with high scores in samples recharged at low altitude, and low scores in samples recharged at high altitude. In addition, it is worth recalling that recharge areas of most of the wells drilled in igneous and metamorphic rocks and in the sediments derived from them (groups 1 and 3) are located at low altitude. Because of their lithology, water samples 
present high concentrations of $\mathrm{Na}^{+}$and $\mathrm{Cl}^{-}$, explaining the association of both ions with $\delta^{18} \mathrm{O}$ (Table 1, Figure 2 and Figure 3).

- VF4 is mainly associated to $\delta^{15} \mathrm{~N}_{\mathrm{NO}}$, with a lower participation of $\mathrm{Na}^{+}$and $\mathrm{Cl}^{-}$. With a $15.03 \%$ of the total variance explained, this last VF represents natural attenuation processes (i.e., denitrification). The association of $\mathrm{Na}^{+}$and $\mathrm{Cl}^{-}$with high $\delta^{15} \mathrm{~N}_{\mathrm{NO} 3}$ values ( $\delta^{15} \mathrm{~N}>15 \%$, according to Kendall et al., 2007) may be attributed to the attenuation processes described in the Selva basin, group 3, where regional flow systems with $\mathrm{Na}^{+}-\mathrm{HCO}_{3}{ }^{-}$facies and reducing conditions, enhanced natural heterotrophic attenuation processes (Puig et al., 2013).

232 Two sample tendencies with positive scores for $\mathrm{SO}_{4}^{2-}, \mathrm{Ca}^{2+}$ and $\mathrm{Mg}^{2+}$ (that is, VF1) are 233 distinguished in a plot VF1 vs. VF2. The first tendency presents high scores for VF2 as well, 234 which links samples with high $\mathrm{SO}_{4}{ }^{2-}, \mathrm{Ca}^{2+}$ and $\mathrm{Mg}^{2+}$ content to high nitrate concentrations 235 (quadrant I in Figure 3a), including samples from aquifer groups 2, 3 and 4 with nitrate 236 concentrations between 280 to $590 \mathrm{mg} \mathrm{NO}_{3}{ }^{-} / \mathrm{L}$. The second one is associated to negative 237 values in VF2, and it is composed of samples from aquifer groups 2 and 4, those related to 238 sedimentary rocks and the sediments derived from these materials. In this case, nitrate 239 concentrations are notably lower, between 2.5 to $119 \mathrm{mg} / \mathrm{L}$, and the sample with the highest 240 VF1 score is the one with the lowest nitrate concentration. Thus, two clear sets of samples 241 with distinct origins for $\mathrm{SO}_{4}{ }^{2-}$ are distinguished in these study areas: one with $\mathrm{SO}_{4}{ }^{2-}$ related to 242 nitrate pollution, and the other with $\mathrm{SO}_{4}{ }^{2-}$ related to natural sources.

243 In Figure 3b, high and low scores for nitrate pollution (VF2) are distributed in both high and 244 low altitude recharge areas (as defined by $\delta^{18} \mathrm{O}$ isotopic compositions, VF3). This indicates a 245 widespread nitrate distribution all over the study areas, being consistent with an intense 246 agricultural activity. However, most of samples in aquifer group 5, which wells are located in 
247 volcanic rocks, present low VF2 values, consistent with the comparatively low pollution

levels in this aquifer type (Table 1).

Finally, when nitrate content (VF2) and nitrate attenuation (VF4) are plotted (Figure 3c), samples with the highest nitrate concentration (with values exceeding $150 \mathrm{mg} \mathrm{NO}_{3}{ }^{-} / \mathrm{L}$ at VF2 scores $>1$ ) are located in quadrants I and II; while quadrants I and IV include those samples affected by natural attenuation (with $\delta^{15} \mathrm{~N}>15 \%$ ). Samples of quadrant I and IV indicate that attenuation processes are active independently of the nitrate concentration. Besides, in some cases, nitrate content has been reduced to values lower than the health standard limits of 50 $\mathrm{mg} / \mathrm{L}$, as represented by the sample with negative scores of VF2. These nitrate attenuation processes have been detected in all aquifers types.

Bivariate plots of selected ions against nitrate concentrations point out their linear increase proportional to manure application. $\mathrm{SO}_{4}{ }^{2-}$ and $\mathrm{Ca}^{2+}$ (both included in $\mathrm{VF} 1$ ) and $\mathrm{Cl}^{-}$ (participating in VF2 and VF3) as major components illustrate this fact (Figure 4). Linear regression equations are estimated for each aquifer lithology using all the available data, despite their $\delta^{15} \mathrm{~N}_{\mathrm{NO} 3}$ value. Such regression equations prevail over two facts: 1) the inherent variability of the manure chemical composition depending on its origin and storage before application; and 2) the heterogeneity of soil processes, which are different, in type and magnitude, depending on the soil nature and the crop type. Therefore, equations indicate the rate of ion concentration changes with increasing nitrate content (slope); that is, the amount of each ion that any unit of nitrate adds to groundwater whether as a direct input or as a result of enhancing geochemical processes; and the expected value of the major component where no fertilization occurs (y-intercept). Such linear increase is quite evident for these three ions, and similar relationships occur for other major components.

Nevertheless, each geological environment show distinct responses to nitrate inputs. Waterrock interaction in igneous and metamorphic rocks (group 1) will depend on the low 
solubility of silicate minerals, and of other processes as cation exchange, which may significantly alter the $\mathrm{Ca}^{2+}: \mathrm{Na}^{+}$ratio and it may be responsible for a wide dispersion of data values with and without the occurrence of nitrate pollution. The large heterogeneity of volcanic deposits (group 5), which may include sedimentary layers among volcanic episodes, also originates a wide range of geochemical values as regards of $\mathrm{SO}_{4}{ }^{2-}$ and $\mathrm{Ca}^{2+}$. However, Moreover, the occurrence of thermal and/or $\mathrm{CO}_{2}$-rich waters in group 1 aquifers may enhance specific weathering processes resulting, for instance, in large chloride concentrations that infiltrating water may dilute.

As already suggested by the PCA results, $\mathrm{SO}_{4}{ }^{2-}$ content may originate from evaporitic rocks (gypsum) dissolution or from manure contribution. These two geochemical paths are also recognized in groups 2 and 4, where sedimentary rocks or their denudation deposits constitute the aquifers: significantly large values of $\mathrm{SO}_{4}{ }^{2-}$ are found at low nitrate concentration $(<75$ mg $\mathrm{NO}_{3}{ }^{-} / \mathrm{L}$ ), whereas a clear linear relationship between them appears as nitrate content increases. Correlation factors, as they appear in Figure 4, are misleading since they represent the whole dataset; exclusion of those points largely affected by gypsum dissolution will turn to larger $\mathrm{R}^{2}$ values proving the influence of manure fertilization on the final groundwater composition.

Denitrification processes also affect such bivariate relationships. In those places where autotrophic nitrate reduction has been proved (group 2 samples, Osona region; Otero et al., 2009), an increase of $\mathrm{SO}_{4}{ }^{2-}$ due to pyrite oxidation will occur coupled to nitrate decreease; whereas heterotrophic attenuation processes will increase alkalinity. Both processes will also have consequences on the gypsum and calcite equilibriums modifying the $\mathrm{Ca}^{2+}$ concentration, yet the neat linear increase of $\mathrm{Ca}^{2+}$ with nitrate in most of the aquifer types might suggest that it directly originates in the manure itself. However, a geochemical insight to calcium 
equilibrium indicates that nitrification of reduced $\mathrm{N}$ from manure generates acidity along with $\mathrm{NO}_{3}{ }^{-}$and it enhances carbonate dissolution. This process can even be accentuated where lime or dolomite are applied as soil neutralizers in agricultural lands (Böhlke, 2002; Choi et al., 2013), increasing $\mathrm{Ca}^{2+}$ and $\mathrm{Mg}^{2+}$ concentrations. Complementarily, the analysis of hydrochemical evolution of pig manure stored in experimental pits showed a decrease of $\mathrm{Ca}^{2+}$ and $\mathrm{Mg}^{2+}$ through time (Vitòria, 2004). Since manure is usually stored for several months before its application, $\mathrm{Ca}^{2+}$ increase shown in Figure 4 may be better attributed to geochemical reactions occurring in the soil and in the subsurface following fertilization than to direct manure contribution. Hence, the observed hydrochemical composition is not just a simple conservative mixture of groundwater with infiltrating slurry and manure lixiviation. Contrarily, $\mathrm{Na}^{+}$and $\mathrm{K}^{+}$showed a conservative behavior in the liquid manure, being their concentrations increased by evaporation (Vitòria, 2004). However, groundwater samples are not specifically rich in both cations (Figure 2), suggesting that other processes as plant uptake, sorption and cation exchange may control their final content in groundwater (Böhlke, 2002).

\section{CONCLUSIONS}

Data from aquifers with distinct lithological environments prove that manure application as fertilizer modifies groundwater hydrochemical composition, turning it notably distinct than the expected natural background given by water-rock interaction and other natural processes. Manure and slurry fertilization homogenize the overall hydrochemistry despite lithological differences, hindering the geochemical interpretation inherent to any regional groundwater resources evaluation study.

Nevertheless, such compositional modifications which, in general, tend to adopt a linear increase (Figure 4, all data) cannot be solely attributed to the effect of direct manure inputs, 
as fertilization may enhance or reduce geochemical processes that control groundwater composition at equilibrium. Therefore accepting that nitrate pollution influences, groundwater regional reports should look for the relationships shown in these aquifers; checking potential influences upon the expected (natural) hydrochemical composition, so a better understanding of the hydrogeological system is attained.

\section{ACKNOWLEDGMENTS}

329 This study has been funded by the Spanish Government CGL2011-29975-c04/01 and /04 330 projects and the 2014SGR-1456 project from the Catalan Government. We want to thanks 331 the collaboration of Natural Park of Volcanic Zone Garrotxa, and the Regional Council of 332 Osona.

334 REFERENCES

335 ACA (Agència Catalana de l'Aigua). Evolució i estat de les aigües subterrànies de Catalunya 336 a conseqüència de la contaminació per nitrats. Generalitat de Catalunya, Departament de 337 Medi Ambient i Habitatge. Barcelona. 2007.

338 Böhlke, J.-K. Groundwater recharge and agricultural contamination. Hydrogeology Journal, 339 2002, 10:153-179. DOI:10.1007/s10040-011-0183-3

340 Boy-Roura, M. Nitrate groundwater pollution and aquifer vulnerability: the case of the Osona 341 region. PhD dissertation. Universitat de Barcelona, 2013.

342 Boy-Roura, M.; Menció, A.; Mas-Pla J. Temporal analysis of spring water data to assess 343 nitrate inputs to groundwater in an agricultural area (Osona, NE Spain). Science of the Total 344 Environment, 2013, 452-453:433-445. DOI: 10.1016/j.scitotenv.2013.02.065 
345 Boy-Roura, M.; Nolan, B.T.; Menció, A.; Mas-Pla, J. Regression model for aquifer 346 vulnerability assessment of nitrate pollution in the Osona región (NE Spain). Journal of 347 Hydrology, 2013, 505:150-162.

348 Burg, A.; Heaton, T.H.E. The relationship between the nitrate concentration and hydrology of 349 a small chalk spring; Israel. Journal of Hydrology, 1998, 204: 68-82.

350 Carbó, L.I.; Flores, M.C.; Herrero M.A. Well site conditions associated with nitrate 351 contamination in a multilayer semiconfined aquifer of Buenos Aires, Argentina. 352 Environmental Geology, 2009, 57:1489-1500.

353 Cho, J.; Kim, S. Increases in bacteria community diversity in subsurface aquifers receiving 354 livestock wastewater input. Applied Environmental Microbiology, 2000, 66:956-965. 355 DOI:10.1128/AEM.66.3.956.965.2000

356 Choi, B.-Y.; Yun, S.-T.; Kim, K.-H.; Choh, S.-J. Geological controlled agricultural 357 contamination and water-rock interaction in an alluvial aquifer: results from hydrochemical 358 study. Environmental Earth Sciences, 2013, 68:203-217. DOI:10.1007/s12665-012-1731-y

359 EEA (European Environmental Agency) European waters-assessment status and pressures. 360 EEA Report, No 8/2012. Copenhagen, Denmark, 2012.

361 Folch, A.; Menció, A.; Puig, R.; Soler, A.; Mas-Pla, J. Groundwater development effects on 362 different scale hydrogeological systems using head, hydrochemical and isotopic data and 363 implications for water resources management: The Selva basin (NE Spain). .Journal of 364 Hydrology, 2011, 403(1):83-102.

365 Helena, B.; Pardo, R.; Vega, M.; Barrado, E.; Fernandez, J.M.; Fernandez, L. Temporal 366 evolution of ground water composition in an alluvial aquifer (Pisuerga River, Spain) by 367 principal component analysis. Water Resources, 2000, 34, 807-816. 
$3692000,228: 37-47$.

370 Kaown, D.; Koh, D.-C.; Lee, K.-K. Effects of groundwater residence time and recharge rate 371 on nitrate contamination deduced from $\delta 18 \mathrm{O}, \delta \mathrm{D}, 3 \mathrm{H} / 3 \mathrm{He}$ and $\mathrm{CFCs}$ in a small agricultural 372 area in Chuncheon, Korea. Journal of Hydrology, 2009, 366:101-111.

373 Katz, B.G.; Chelette, A.R.; Pratt, T.R. Use of chemical and isotopic tracers to assess nitrate 374 contamination and ground-water age, Woodville Karst Plain, USA. Journal of Hydrology, $3752004,289: 36-61$.

376 Kendall, C.; Elliott, E.M.; Wankel; S.D. Tracing anthropogenic inputs of nitrogen to 377 ecosystems, Chapter 12, In: R.H. Michener and K. Lajtha (Eds.), Stable Isotopes in Ecology 378 and Environmental Science, 2007, 2nd edition, Blackwell Publishing, p. 375-449.

379 Korbel, K.L.; Hancock, P.J.; Serov, P.; Lim, R.O.; Hose, G.C. Groundwater ecosystems vary 380 with land use across a mixed agricultural landscape. Journal of Environmental Quality, 2013, $38142: 380-390$.

382 Korbel, K.L.; Hose, G.C. A tiered framework for assessing groundwater ecosystems health. 383 Hydrobiologia, 2011, 661:329-349. DOI:10.1007/s10750-010-0541z

384 Lapworth, D.J.; Baran, N.; Stuart, M.E.; Ward, R.S. Emerging organic contaminants in 385 groundwater: A review of sources, fate and occurrence. Environmental Pollution, 2012, $386 \quad 163: 287-303$.

387 Masetti, M.; Poli, S.; Sterlacchini, S.; Beretta, G.P.; Facchi, A. Spatial and statistical 388 assessment of factors influencing nitrate contamination in groundwater. Journal of 389 Environmental Management, 2008, 86:272-281. 
390 Menció, A.; Boy, M.; Mas-Pla, J. Analysis of vulnerability factors that control nitrate 391 occurrence in natural springs (Osona Region, NE Spain). Science of the Total Environment, 392 2011, 409:3049-3058. DOI: 10.1016/j.scitotenv.2011.04.048

393 Menció, A.; Folch, A.; Mas-Pla, J. Identifying key parameters to differentiate groundwater 394 flow systems using multifactorial analysis. Journal of Hydrology, 2012, 472-473:301-313. 395 DOI: 10.1016/j.jhydrol.2012.09.030

396 Menció, A.; Korbel, K.L.; Hose, G.C. River-aquifer interactions and their relationship to 397 stygofauna assemblages: A case study of the Gwydir River alluvial aquifer (New South 398 Wales, Australia). Science of the Total Enviornment, 2014, 479-480:292-305. DOI: 399 10.1016/j.scitotenv.2014.02.009

400 Menció, A.; Mas-Pla, J. Assessment by multivariate analysis of surface water -groundwater 401 interactions in urbanized Mediterranean streams. Journal of Hydrology, 2008, 352 (3): $355-$ 402 366.DOI:10.1016/j.jhydrol.2008.01.014

403 Menció, A.; Mas-Pla, J.; Otero, N.; Soler, A. Nitrate as a tracer of groundwater flow in a 404 fractured multi-layered aquifer. Hydrological Sciences Journal, 2011, 56(1):108-122. $405 \quad$ DOI:10.1080/02626667.2010.543086

406 Murray, K.E.; Thomas, S.M.; Bodour, A. Prioritizing research for trace pollutants and 407 emerging contaminants in the freshwater environment. Environmental Pollution, 2010, $408 \quad 158: 3462-71$.

409 Otero, N.; Torrentó, C.; Soler, A.; Menció, A.; Mas-Pla, J. Monitoring groundwater nitrate 410 attenuation in a regional system coupling hydrogeology with multi-isotopic methods: the case 411 of Plana de Vic (Osona, Spain). Agriculture Ecosystems and Environment, 2009, 133:103412 113. DOI: $10.1016 /$ j.agee.2009.05.007 
413 Puig, R. (2014). Multi-isotopic and statistical approaches to trace nitrate pollution sources 414 and assess natural attenuation in groundwater: examples from nitrate vulnerable zones in Catalonia (NE Spain). PhD Dissertation, Universitat de Barcelona.

Puig, R.; Folch, A.; Menció, A.; Soler, A.; Mas-Pla, J. Multi-isotopic study (15N, 34S, 18O, 417 13C) to identify processes affecting nitrate and sulfate in response to local and regional 418 groundwater mixing in a large-scale flow system. Applied Geochemistry, 2013, 32:129-141. 419 DOI: 10.1016/j.apgeochem.2012.10.014

420 Re, V.; Sacchi, E.; Mas-Pla, J.; Menció, A.; El Amrani, N. Identifying the effects of human 421 pressure on groundwater quality to support water management strategies in coastal regions: A 422 multi-tracer and statistical approach (Bou-Areg region, Morocco). Science of the Total 423 Environment, 2014, 500-501: 211-223. DOI: 10.1016/j.scitotenv.2014.08.115

424 Soler, D.; Zamorano, M.; Roqué, C.; Menció, A.; Boy, M.; Bach, J.; Brusi, D.; Mas-Pla J. 425 Evaluación de la influencia de las estructuras tectónicas en la recarga del sistema 426 hidrogeológico de la depresión del Alt Empordà (NE España) en base a datos hidroquímicos 427 e isotópicos. II Congreso Ibérico de las Aguas Subterráneas, CIAS2014, 2014.

428 Spalding, R.F; Exner, M. E. Occurrence of nitrate in ground-water-a review. Journal of 429 Environmental Quality, 1993, 22:392-402.

430 Stein, H.; Kellermann, C.; Schmidt, S.I.; Brielmann, H.; Steube, C.; Berkhoff, S.E.; Fuchs, 431 A.; Hahn, H.J.; Thulin, B.; Griebler, C. The potential use of fauna and bacteria as ecological 432 indicators for assessment of groundwater quality. Journal of Environmental Monitoring, $4332010,12: 242-254$. 
6
434 Vitòria, L. Estudi multi-istòpic $(15 \mathrm{~N}, 34 \mathrm{~S}, 13 \mathrm{C}, 18 \mathrm{O}, \mathrm{D}, 87 \mathrm{Sr} / 86 \mathrm{Sr})$ de les aigües 435 subterrànies contaminades per nitrats d'orígen agrícola i ramader. $\mathrm{PhD}$ dissertation. 436 Universitat de Barcelona, 2004.

437 Vitòria, L.; Soler, A.; Canals, A.; Otero, N. Environmental isotopes (N, S, C, O, D) to 438 determine natural attenuation processes in nitrate contaminated waters: example of Osona 439 (NE Spain). Applied Geochemistry, 2008, 23:3597-3611. 
443

444 Figure 1: Geographical and geological setting of the distinct study areas.

445 Figure 2. Box plots of the main hydrochemical parameters according to the aquifer groups 446 and nitrate concentrations ranges: Low nitrate concentrations refer to values below $50 \mathrm{mg} / \mathrm{L}$, 447 and high nitrate concentrations refer to values above $50 \mathrm{mg} / \mathrm{L}$ (see SI2 for details). Legend: 448 Boxes represent the 25 and 75 percentiles and the median; while a white line represents the 449 mean value. Bars define the 10 and $90 \%$ percentile, and dots refer to extreme values.

450 Figure 3. PCA scores distribution of the different samples, considering denitrification, 451 plotted according the lithological group and the $\delta^{15} \mathrm{~N}_{\mathrm{NO}}$, content: a) VF1 vs VF2, b) VF3 vs 452 VF2, and c) VF4 vs VF2.

453 Figure 4. Bivariate relationships of $\mathrm{SO}_{4}{ }^{2-}, \mathrm{Ca}^{2+}$ and $\mathrm{Cl}^{-}$vs. $\mathrm{NO}_{3}{ }^{-}$. Linear regression equations 454 are calculated for all the samples of the group, disregarding their $\delta^{15} \mathrm{~N}$ value. Legend: red 455 circles, samples with $\delta^{15} \mathrm{~N}>15 \%$; black circles, samples with $\delta^{15} \mathrm{~N}<15 \%$; white circles, 456 samples with $\delta^{15} \mathrm{~N}$ data not available. 
TABLES

460 Table 1: Mean values and standard errors of the main physicochemical characteristics of the 461 different aquifer groups, differentiating samples of low and high nitrate content.

\begin{tabular}{|c|c|c|c|c|c|c|c|c|c|c|}
\hline & \multicolumn{2}{|c|}{$\begin{array}{l}\text { G1- Igneous and } \\
\text { metamorphic rocks }\end{array}$} & \multicolumn{2}{|c|}{ G2- Sedimentary rocks } & \multicolumn{2}{|c|}{$\begin{array}{l}\text { G3- Aquifers derived } \\
\text { from igneous and } \\
\text { metamorphic rocks }\end{array}$} & \multicolumn{2}{|c|}{$\begin{array}{l}\text { G4- Aquifers derived } \\
\text { from sedimentary rocks }\end{array}$} & \multicolumn{2}{|c|}{ G5- Volcanic materials } \\
\hline & $<50 \mathrm{mg} / \mathrm{L}$ & $>50 \mathrm{mg} / \mathrm{L}$ & $<50 \mathrm{mg} / \mathrm{L}$ & $>50 \mathrm{mg} / \mathrm{L}$ & $<50 \mathrm{mg} / \mathrm{L}$ & $>50 \mathrm{mg} / \mathrm{L}$ & $<50 \mathrm{mg} / \mathrm{L}$ & $>50 \mathrm{mg} / \mathrm{L}$ & $<50 \mathrm{mg} / \mathrm{L}$ & $>50 \mathrm{mg} / \mathrm{L}$ \\
\hline $\begin{array}{l}\text { Number } \\
\text { of wells }\end{array}$ & 9 & 4 & 28 & 36 & 15 & 27 & 22 & 29 & 29 & 5 \\
\hline $\mathrm{EC}(\mu \mathrm{S} / \mathrm{cm})$ & $819 \pm 110$ & $915 \pm 135$ & $819 \pm 70$ & $1124 \pm 65$ & $841 \pm 72$ & $1073 \pm 78$ & $770 \pm 27$ & $1070 \pm 64$ & $623 \pm 21$ & $779 \pm 31$ \\
\hline $\mathrm{pH}$ & $7.18 \pm 0.14$ & $6.99 \pm 0.04$ & $7.35 \pm 0.09$ & $7.43 \pm 0.06$ & $7.47 \pm 0.12$ & $7.28 \pm 0.08$ & $7.18 \pm 0.04$ & $7.08 \pm 0.04$ & $7.47 \pm 0.06$ & $7.25 \pm 0.21$ \\
\hline $\mathrm{Eh}(\mathrm{mV})$ & $236.7 \pm 62.1$ & $386.5 \pm 39.3$ & $190.1 \pm 20.1$ & $247.4 \pm 27.4$ & $354.9 \pm 38.7$ & $379.8 \pm 8.3$ & $161.0 \pm 13.5$ & $164.3 \pm 17.3$ & $274.6 \pm 21.0$ & $240.0 \pm 10.0$ \\
\hline $\mathrm{T}\left({ }^{\circ} \mathrm{C}\right)$ & $17.4 \pm 0.5$ & $16.9 \pm 0.3$ & $15.4 \pm 0.6$ & $15.9 \pm 0.4$ & $16.3 \pm 0.4$ & $16.4 \pm 0.2$ & $15.1 \pm 0.4$ & $13.2 \pm 0.2$ & $14.5 \pm 0.6$ & $14.5 \pm 0.4$ \\
\hline $\mathrm{O}_{2}(\mathrm{mg} / \mathrm{L})$ & $1.5 \pm 0.6$ & $3.9 \pm 1.4$ & $4.0 \pm 0.6$ & $4.0 \pm 0.5$ & $3.7 \pm 1.1$ & $5.2 \pm 0.5$ & $4.6 \pm 0.6$ & $4.4 \pm 0.4$ & $8.0 \pm 0.6$ & $7.6 \pm 1.3$ \\
\hline $\mathrm{HCO}_{3}^{-}(\mathrm{mg} / \mathrm{L})$ & $368.1 \pm 59.6$ & $346.9 \pm 40.0$ & $418.3 \pm 15.4$ & $388.0 \pm 13.0$ & $355.1 \pm 34.4$ & $360.7 \pm 13.5$ & $411.9 \pm 18.6$ & $407.4 \pm 13.1$ & $284.8 \pm 13.0$ & $341.7 \pm 39.0$ \\
\hline $\mathrm{Cl}^{-}(\mathrm{mg} / \mathrm{L})$ & $101.0 \pm 24.7$ & $99.2 \pm 42.8$ & $42.4 \pm 6.7$ & $94.9 \pm 10.4$ & $86.1 \pm 15.1$ & $91.8 \pm 11.9$ & $16.0 \pm 1.6$ & $73.3 \pm 12.4$ & $16.1 \pm 2.2$ & $30.7 \pm 10.4$ \\
\hline $\mathrm{SO}_{4}{ }^{2-}(\mathrm{mg} / \mathrm{L})$ & $35.9 \pm 5.7$ & $57.2 \pm 8.6$ & $132.4 \pm 46.4$ & $164.3 \pm 32.1$ & $68.4 \pm 16.8$ & $98.1 \pm 12.4$ & $43.5 \pm 5.4$ & $184.6 \pm 34.6$ & $48.0 \pm 6.5$ & $41.4 \pm 8.2$ \\
\hline $\mathrm{NO}_{3}^{-}(\mathrm{mg} / \mathrm{L})$ & $13.7 \pm 4.2$ & $105.3 \pm 20.3$ & $17.0 \pm 2.5$ & $166.3 \pm 19.4$ & $18.6 \pm 4.4$ & $137.5 \pm 16.6$ & $25.4 \pm 2.7$ & $172.2 \pm 25.2$ & $23.9 \pm 2.4$ & $71.4 \pm 10.0$ \\
\hline $\mathrm{Na}^{+}(\mathrm{mg} / \mathrm{L})$ & $104.2 \pm 38.0$ & $79.7 \pm 18.6$ & $34.8 \pm 4.2$ & $54.3 \pm 7.5$ & $63.5 \pm 12.0$ & $56.4 \pm 5.1$ & $12.5 \pm 1.4$ & $42.0 \pm 5.6$ & $16.5 \pm 1.5$ & $21.5 \pm .9$ \\
\hline $\mathrm{K}^{+}(\mathrm{mg} / \mathrm{L})$ & $2.2 \pm 0.4$ & $1.0 \pm 0.3$ & $4.4 \pm 1.7$ & $8.5 \pm 2.4$ & $2.4 \pm 0.4$ & $5.8 \pm 3.0$ & $2.8 \pm 0.6$ & $8.8 \pm 2.1$ & $7.6 \pm 0.7$ & $6.9 \pm 1.7$ \\
\hline $\mathrm{Ca}^{2+}(\mathrm{mg} / \mathrm{L})$ & $82.6 \pm 14.0$ & $127.5 \pm 21.5$ & $132.6 \pm 16.2$ & $185.7 \pm 10.1$ & $110.7 \pm 12.7$ & $166.3 \pm 9.7$ & $135.8 \pm 7.1$ & $196.0 \pm 10.8$ & $87.2 \pm 4.5$ & $89.5 \pm 8.4$ \\
\hline $\mathrm{Mg}^{2+}(\mathrm{mg} / \mathrm{L})$ & $14.6 \pm 3.6$ & $22.0 \pm 3.5$ & $37.4 \pm 5.4$ & $38.2 \pm 3.8$ & $19.3 \pm 2.0$ & $22.7 \pm 2.4$ & $21.0 \pm 1.1$ & $44.1 \pm 5.6$ & $19.5 \pm 1.2$ & $34.1 \pm 3.5$ \\
\hline
\end{tabular}


1

2

3

4

5

6

7

8

9

10

11

12

13

14

15

16

17

18

19

20

21

22

23

24

25

26

27

28

29

30

31

32

41

42

43

44

45

46

47

48

49

50

51

52

53

54

55

56

57

58

59

60

61

62

63

64

65

465 Table 2. Loadings obtained in the second PCA, including $\delta^{15} \mathrm{~N}_{\mathrm{NO} 3}$, among the different 466 parameters.

\begin{tabular}{l|cccc}
\hline & VF1 & VF2 & VF3 & VF4 \\
\hline $\mathrm{SO}_{4}{ }^{2-}(\mathrm{mg} / \mathrm{L})$ & $\underline{0.965}$ & 0.008 & -0.005 & 0.039 \\
$\mathrm{Mg}^{2+}(\mathrm{mg} / \mathrm{L})$ & $\underline{0.885}$ & 0.181 & 0.007 & 0.249 \\
$\mathrm{Ca}^{2+}(\mathrm{mg} / \mathrm{L})$ & $\underline{0.740}$ & $\underline{0.562}$ & 0.004 & 0.035 \\
$\mathrm{EC}(\mu \mathrm{S} / \mathrm{cm})$ & $\underline{0.641}$ & $\underline{0.546}$ & $\underline{0.425}$ & 0.184 \\
$\mathrm{NO}_{3}{ }^{-}(\mathrm{mg} / \mathrm{L})$ & 0.121 & $\underline{0.949}$ & 0.112 & 0.057 \\
$\delta^{18} \mathrm{O}_{\mathrm{H} 2 \mathrm{O}}(\%)$ & -0.238 & 0.097 & $\underline{0.848}$ & -0.178 \\
$\mathrm{Na}^{+}(\mathrm{mg} / \mathrm{L})$ & 0.295 & 0.054 & $\underline{0.738}$ & $\underline{0.426}$ \\
$\mathrm{Cl}^{-}(\mathrm{mg} / \mathrm{L})$ & 0.289 & $\underline{0.520}$ & $\underline{0.601}$ & $\underline{0.405}$ \\
$\delta^{15} \mathrm{~N}_{\mathrm{NO} 3}(\%)$ & 0.113 & 0.085 & 0.047 & $\underline{0.935}$ \\
\hline Eigenvalue & 2.928 & 1.837 & 1.821 & 1.352 \\
$\%$ Variance & 32.53 & 20.41 & 20.23 & 15.03 \\
\hline
\end{tabular}

467

.




\section{Figure 1}

Click here to download high resolution image

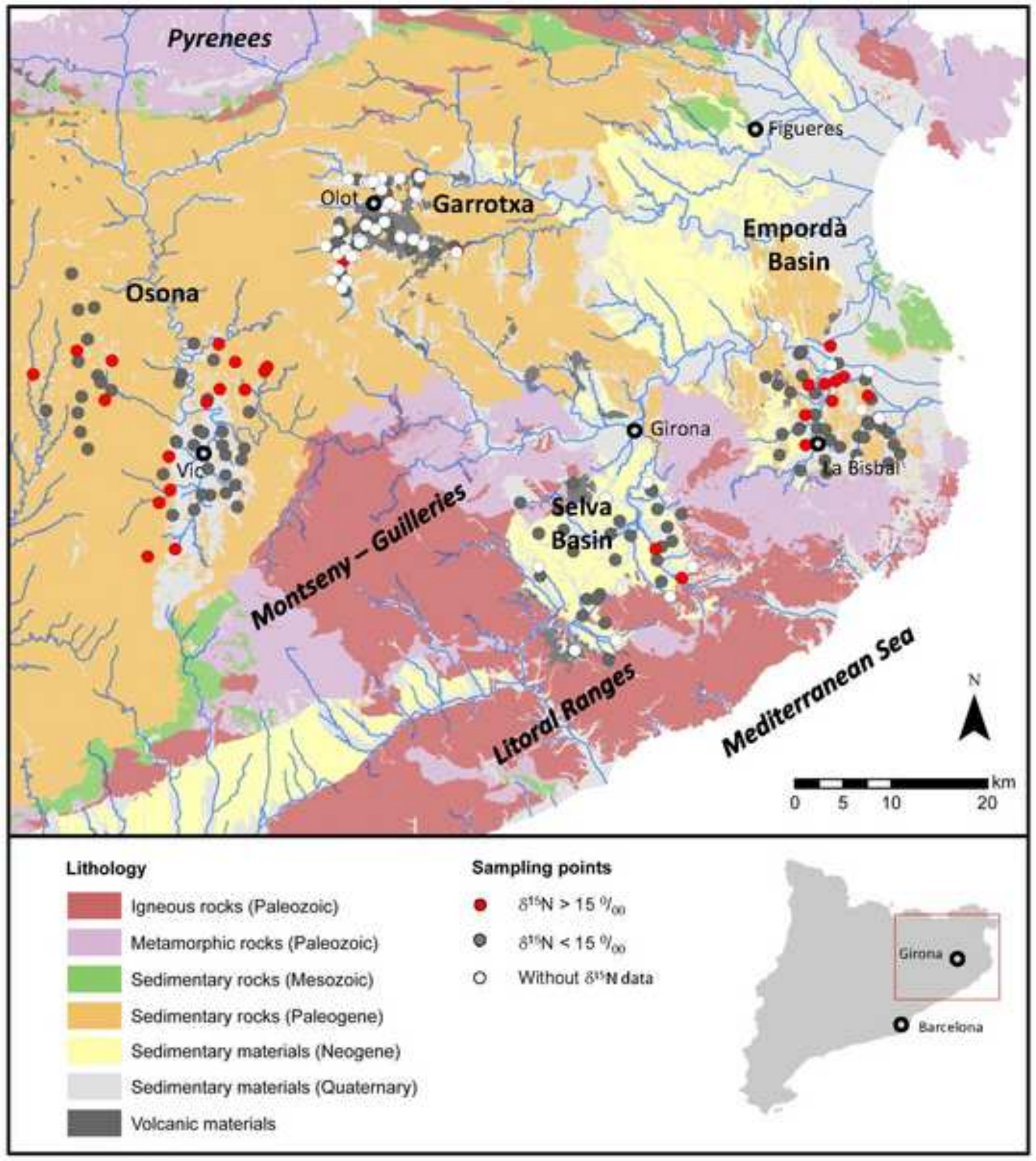



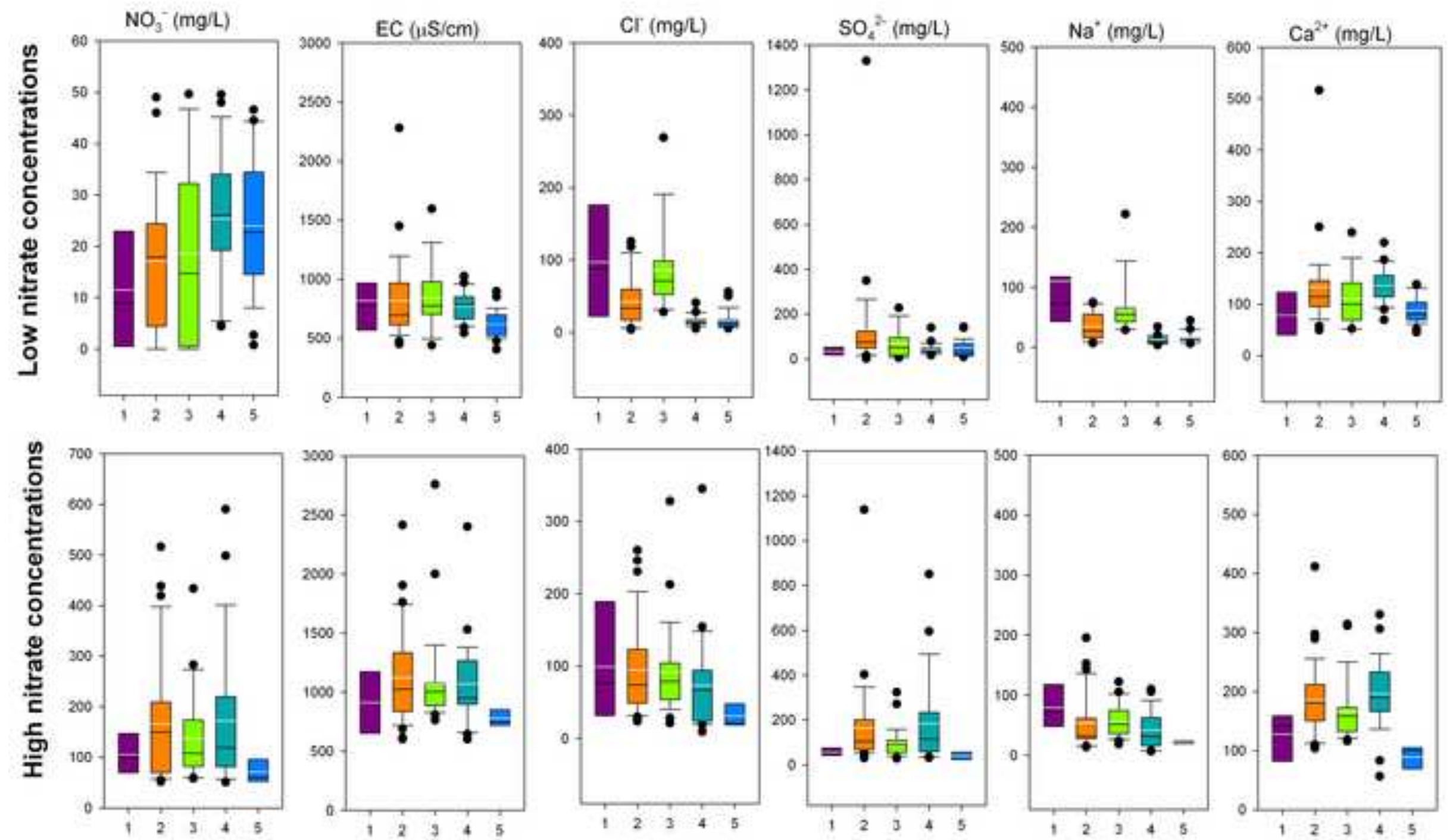

Aquifer groups 

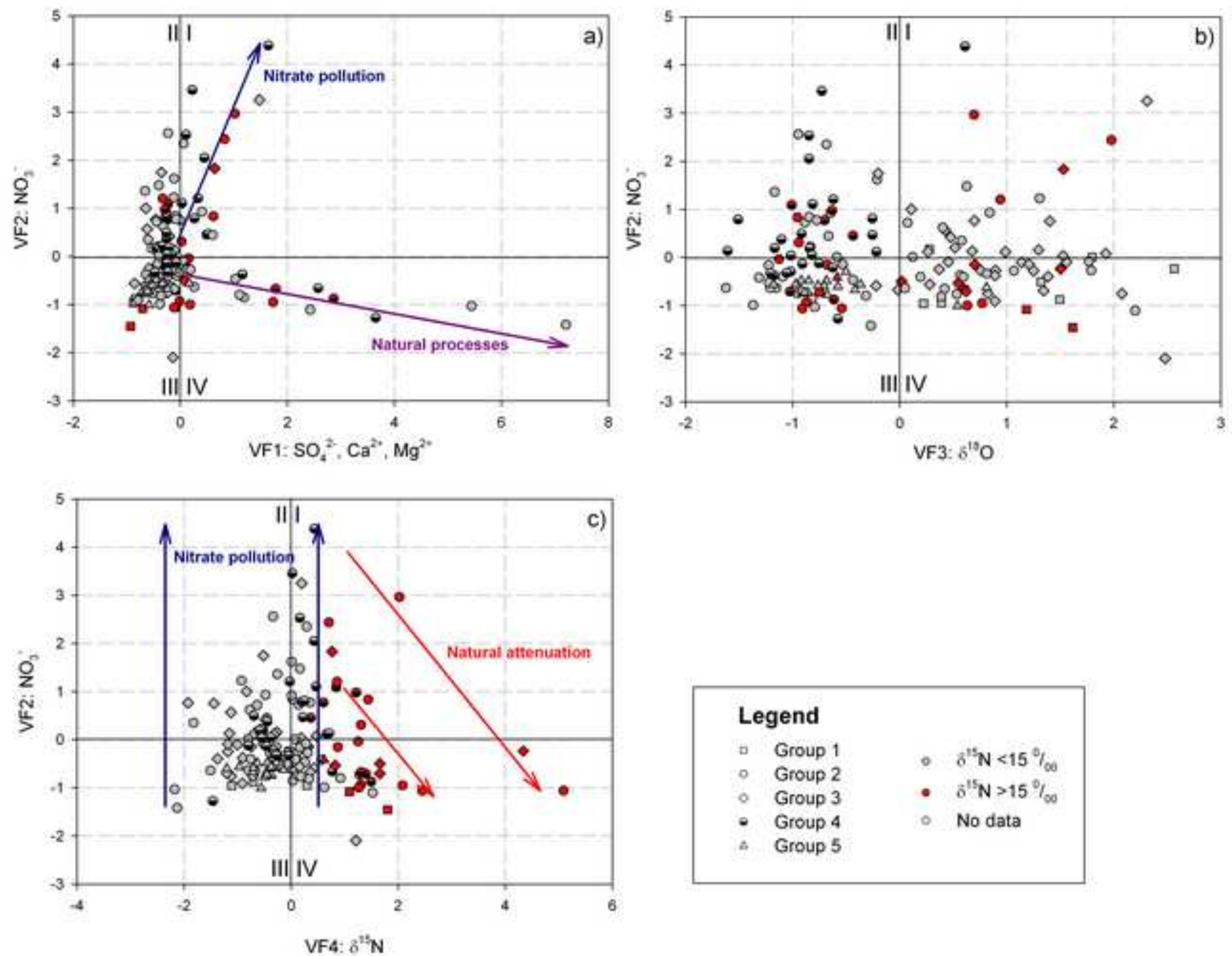

\section{Legend}

- Group 1

Group 2

Group 3

Group 4

4 Group 5
) 

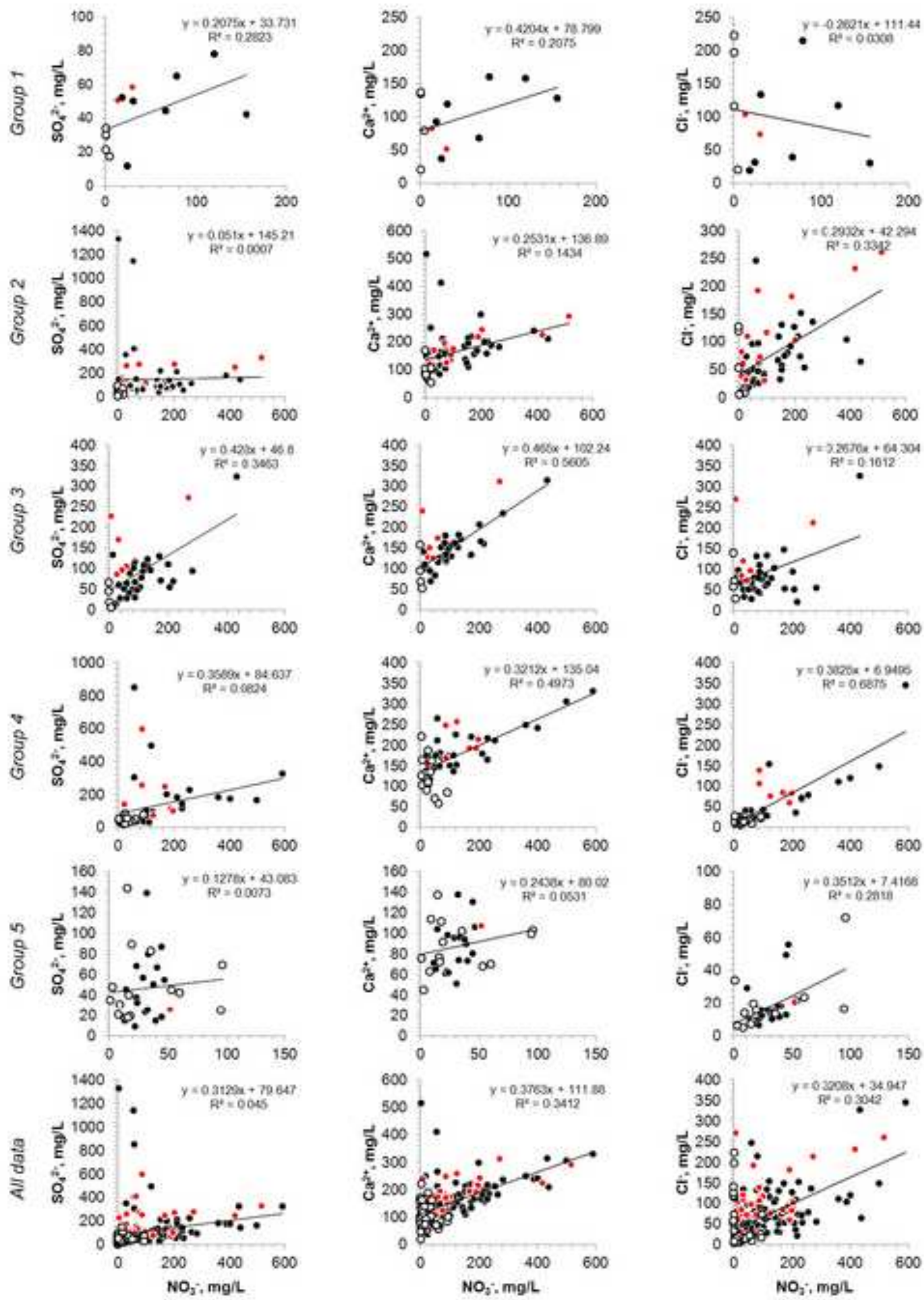